Article

\title{
Quantification of Cheese Yield Reduction in Manufacturing Parmigiano Reggiano from Milk with Non-Compliant Somatic Cells Count
}

\author{
Piero Franceschi ${ }^{1}\left(\mathbb{D}\right.$, Michele Faccia ${ }^{2}\left(\mathbb{D}\right.$, Massimo Malacarne $\left.{ }^{1, *} \mathbb{(}\right)$, Paolo Formaggioni ${ }^{1, *}$ and \\ Andrea Summer ${ }^{1}$ D \\ 1 Department of Veterinary Science, University of Parma, Via del Taglio 10, I-43126 Parma, Italy; \\ piero.franceschi@unipr.it (P.F.); andrea.summer@unipr.it (A.S.) \\ 2 Department of Soil, Plant and Food Sciences, University of Bari. Via Amendola 165/A, 70125 Bari, Italy; \\ michele.faccia@uniba.it \\ * Correspondence: massimo.malacarne@unipr.it (M.M.); paolo.formaggioni@unipr.it (P.F.); \\ Tel.: +39-0521032615 (M.M.); +39-0521032614 (P.F.)
}

Received: 15 January 2020; Accepted: 15 February 2020; Published: 18 February 2020

\begin{abstract}
The mammary gland inflammation process is responsible for an increased number of somatic cells in milk, and transfers into the milk of some blood components; this causes alterations in the chemical composition and physico-chemical properties of milk. For this reason, somatic cell count (SCC) is one of the most important parameters of milk quality; therefore, European Union (EU) Regulation no 853/2004 has stated that it must not exceed the limit value of 400,000 cells/mL. The research aimed to compare chemical composition, cheese yield, and cheesemaking losses of two groups of vat milks used for Parmigiano Reggiano production, characterized by different SCC levels. During two years, ten cheesemaking trials were performed in ten different cheese factories. In each trial, two cheesemaking processes were conducted in parallel: one with low SCC milk (below 400,000 cells/mL; Low Cell Count (LCC)) and the other with high SCC milk (400,000-1,000,000 cells/mL; High Cell Count (HCC)). For each trial, vat milk and cooked whey were analyzed; after 24 months of ripening, cheeses were weighed to calculate cheese yield. The HCC group had lower casein content ( 2.43 vs. $2.57 \mathrm{~g} / 100 \mathrm{~g} ; p \leq 0.05)$ and number $(77.03 \%$ vs. $77.80 \% ; p \leq 0.05)$, lower phosphorus (88.37 vs. $92.46 \mathrm{mg} / 100 \mathrm{~g} ; p \leq 0.05)$ and titratable acidity ( $\left.3.16 \mathrm{vs} .3 .34^{\circ} \mathrm{SH} / 50 \mathrm{~mL} ; p \leq 0.05\right)$ compared to LCC. However, chloride (111.88 vs. $104.12 \mathrm{mg} / 100 \mathrm{~g} ; p \leq 0.05)$ and $\mathrm{pH}$ (6.77 vs. 6.71; $p \leq 0.05)$ were higher. Fat losses during cheesemaking were higher (20.16 vs. $16.13 \%)$. After 24 months of ripening, cheese yield was $8.79 \%$ lower for HCC milk than LCC (6.74 vs. $7.39 \mathrm{~kg} / 100 \mathrm{~kg} ; p \leq 0.05)$.
\end{abstract}

Keywords: Parmigiano Reggiano cheese; somatic cells; milk composition; cheese yield; cheesemaking losses

\section{Introduction}

Mastitis is the inflammation of the mammary gland caused by bacterial infection. As a response to the inflammation, the number of macrophages, leucocytes, and polymorphonuclear cells strongly increases, causing a high level of the somatic cells in milk [1]. Somatic cell count (SCC) is one of the most important parameters of milk quality, both under the safety and technological point of views. As to safety, a high SCC level indicates poor hygienic quality and possible presence of pathogens. In order to protect the consumer's health, the law (European Union (EU) Regulation no 853/2004) [2] has regulated this parameter for cow milk. In particular, the value (expressed as rolling geometric mean calculated over a period of three months, with at least one sampling per month) must not exceed the limit value of 400,000 cells/mL. Besides hygienic concerns, a high SCC level negatively influences the technological 
properties of milk, and both the coagulation process and the chemical-sensory characteristics of the cheeses tend to worsen. Several authors have investigated the causes of technological worsening, and they can be summarized in increased levels of casein passing into the soluble phase, greater proteolytic activity, and modifications of the balance of mineral salts [3-5].

An important issue connected with the application of Regulation 853/2004 [2] is that the limit of 400,000 cells $/ \mathrm{mL}$ is calculated over a three-month period. During this period, the risk of milk not complying the legal limit that reaches the dairy transformation, does exist. Summer et al. [6] reported that $10.71 \%$ of the samples collected from free stalls in the Parmigiano Reggiano production area (Italy), exceeded the legal limit of milk production from 2006 to 2008. This was confirmed by data of the Lombardia and Emilia Romagna Experimental Zootechnical Institute (IZSLER, Italy). According to these results, about $10 \%$ of milk production in 2018 in these areas exceeded the 400,000 cells $/ \mathrm{mL}$ limit [7]. These milks are mainly concentrated in the summer period [6], when the cows are subject to stress due to the hot and humid climate typical of the Po valley plain [8].

Two of the most produced cheeses in Lombardy and Emilia-Romagna regions are Grana Padano and Parmigiano Reggiano. Both have been recognized as EU Protected Designation of Origin (PDO) products [9] and are very similar from a chemical, technological, and nutritional point of view [10], being hard cooked cheeses manufactured by partially skimmed raw milk, added with autochthonous starter culture. According to the official protocol, partially skimmed milk from evening milking is merged with the full cream morning milk (about 50:50 v/v), giving rise to "vat milk". Previous studies conducted on Parmigiano Reggiano reported wide variations of the composition of the vat milk throughout the year, and a significant decrease of the cheese yield when the milk somatic cells count exceeded 300,000 cells/mL [11,12]. Considering the importance of cheese yield on the economic efficiency of Parmigiano Reggiano cheesemaking, a specific study aiming to quantify the cheese yield capacity of milk with different levels of somatic cells is highly required. Such information could give a useful contribution to quantify the right remuneration of milk, motivating the breeders to make investments for reducing the somatic cells content. The aim of the present research is to compare chemical composition, cheese yield, and cheesemaking losses (during manufacturing to Parmigiano Reggiano) of milk with non-law-complying and law-complying SCC.

\section{Materials and Methods}

\subsection{Parmigiano Reggiano Cheesemaking Process}

Cheeses were produced according to the official protocol of Parmigiano Reggiano PDO cheese. Although the protocol does not include breed restrictions and allows commingling milk coming from different farms, the milk used in the experimentations was collected only from Italian Friesian cattle herds. Moreover, each cheesemaking trial was performed using milk derived from a single herd.

Vat milk was obtained by commingling the partially skimmed evening milk and the full cream morning milk. In brief, the whole milk of evening milking (WE-milk) was collected from the farm and transported to the cheese factory where it was placed into the creaming tank. Overnight, the cream was separated naturally from the milk and was collected. The morning after, the partially skimmed milk

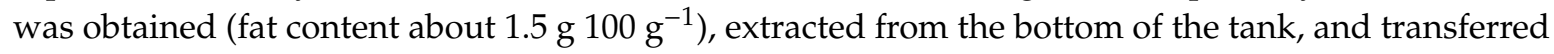
into the cheesemaking vat; the same amount of the whole milk that was obtained by the morning milking of the same herd was added. The final merged milk was lower in fat, containing about $2.6 \mathrm{~g}$ $100 \mathrm{~g}^{-1}$ fat, with a fat to casein ratio of about 1-1.1. It is called vat milk (V-milk) and, before undergoing the cheesemaking process, is added with natural whey starter culture $\left(2.5-3\right.$ liters $\left.100 \mathrm{~kg}^{-1}\right)$. The whey starter culture was obtained by spontaneous acidification of cooked whey (C-whey), deriving from the cheesemaking of the previous day. The inoculated vat milk was heated to $33^{\circ} \mathrm{C}$ and clotted with $2.5-3 \mathrm{~g} 100 \mathrm{~kg}^{-1}$ of commercial calf rennet (1:120,000 strength). After 10-12 min, coagulation occurred; the curd was then cut into small granules (having approximately the size of a rice grain), and heated by increasing temperature to $55^{\circ} \mathrm{C}$. After cooking, the small curd particles were left to 
deposit at the bottom of the vat by decantation, and a whole curd mass was formed. During this time, the temperature remained approximately $53-55{ }^{\circ} \mathrm{C}$. The curd mass was then removed from the vat, divided into two parts, and placed into molds for two day. They were periodically turned over to promote syneresis and whey draining. The cheese wheels were then salted in brine for a period of 20 days before entering the ripening room, where they remained for at least 24 months.

\subsection{Experimental Design}

Over a period of two years, ten comparative cheesemaking trials were performed in ten different cheese factories located in the Parmigiano Reggiano production area. In each trial, two cheesemaking processes were performed in parallel: one using V-milk coded as Low Cell Count (LCC) and the other using V-milk coded as High Cell Count (HCC). The classification LCC or HCC is based on SCC of the whole evening milk: LCC contained less than 400,000 cells/mL, whereas HCC contained more than 400,000 cells $/ \mathrm{mL}$, but less than 1,000,000 cells $/ \mathrm{mL}$.

\subsection{Analytical Methods}

In each cheesemaking trial, the following type of samples were collected: WE-milk taken from the tank of the farm; V-milk, taken from the vat before the addition of the natural whey starter; C-whey, taken from the vat after the extraction of the cheese, and stirred for $5 \mathrm{~min}$. Sodium merthiolate $\left(0.02 \mathrm{~g} / 100 \mathrm{~mL}\right.$, as preservative) was added to all samples, which were cooled to $5{ }^{\circ} \mathrm{C}$, and immediately transported to the laboratory for analyses.

The following tests were performed: somatic cells on WE- and V-milk using the fluoro-opto-electronic method with Fossomatic (Foss Electric, Hillerød, Denmark) [13]; fat content on V-milk by mid-infrared spectroscopy [14] with Milko-Scan FT6000 (Foss Electric); fat content of C-whey was determined by the volumetric Gerber method [15].

Total N (TN), non-casein N (NCN), and non-protein N (NPN) on V-milk, acid whey at pH 4.6 and Trichloroacetic acid (TCA $120 \mathrm{~g} / \mathrm{L}$; Carlo Erba Reagents, Milan, Italy) filtered whey, respectively, were determined by the Kjeldahl method, which was performed using a DK6 Digestor and UDK126A Distiller (VELP Scientifica, Usmate, Italy), according to the Association of Official Analytical Chemists (AOAC) standards [16-18]. From these analyses, crude protein $(\mathrm{TN} \times 6.38 / 1000)$, casein $((\mathrm{TN}-\mathrm{NCN})$ $\times 6.38 / 1000)$, casein number $((\mathrm{TN}-\mathrm{NCN}) \times 100 / \mathrm{TN}), \mathrm{NPN} \times 6.38(\mathrm{NPN} \times 6.38 / 1000)$, true protein $((\mathrm{TN}-\mathrm{NPN}) \times 6.38 / 100)$ were calculated, as described by Summer et al. [12]. TN was also determined on C-whey, also by Kjeldahl [12].

The content of phosphorus was measured on V-milk and C-whey by colorimetric method [19] and those of calcium and magnesium by atomic absorption spectrometry (AAS Perkin-Elmer $1100 \mathrm{~B}$, Waltham, MA, USA), as reported by Malacarne et al. [19]; chloride were determined on V-milk by argentometric Volhard method [20].

The $\mathrm{pH}$ was measured on V-milk with potentiometer Crison (Crison Instruments, E-08328 Barcelona, Spain), and titratable acidity by titration with sodium hydroxide solution $(0.25 \mathrm{~N})$ of $50 \mathrm{~mL}$ of V-milk using as indicator $2 \mathrm{~mL}$ of phenolphthalein in ethanol (20 g/L; Carlo Erba Reagents), according to the Soxhlet-Henkel method [12].

Somatic cell score $\left(S C S=\left(\log _{2}(S C C / 100)+3\right)[21]\right.$ and fat-to-casein ratio values were calculated on WE-milk and V-milk, respectively.

For yield calculation, in each cheesemaking, V-milk was weighed directly in the vat, before the addition of the starter. Both the two cheese wheels resulting from each cheesemaking were weighed at 24 months of ripening; the moisture content of the cheese after drying at $102{ }^{\circ} \mathrm{C}$ was also determined [22].

The actual cheese yield (ACY; $\mathrm{kg}$ of cheese /100 kg of milk) was calculated as follows:

$$
\mathrm{ACY}=\mathrm{cw} \times 100 / \mathrm{mw},
$$


where: $\mathrm{ACY}=$ actual cheese yield; $\mathrm{cw}=$ cheese weight, expressed in $\mathrm{kg} ; \mathrm{mw}=$ milk weight, also expressed in $\mathrm{kg}$.

The adjusted dry cheese yield (ADY; $\mathrm{kg}$ of cheese /100 kg of milk) was calculated, according to the following formula:

$$
\mathrm{ADY}=\mathrm{ACY} \times(100-\mathrm{CMC}) / 100,
$$

where: $\mathrm{ADY}=$ adjusted yield; $\mathrm{CMC}=$ cheese moisture content.

Finally, the estimated cheesemaking losses (ECL) values of protein, casein, fat, calcium, phosphorus, and magnesium were calculated as follows:

$$
\mathrm{ECL}=(\mathrm{C} \text {-whey }) \times 100 /(\mathrm{V}-\mathrm{milk}),
$$

where ECL is expressed as percentage; (C-whey) = concentration in whey, expressed as $\mathrm{g} / 100 \mathrm{~g}$ $(\mathrm{mg} / 100 \mathrm{~g}$ for $\mathrm{Ca}, \mathrm{P}, \mathrm{Mg}) ;(\mathrm{V}$-milk $)=$ concentration in milk, expressed as $\mathrm{g} / 100 \mathrm{~g}(\mathrm{mg} / 100 \mathrm{~g}$ for Ca, $\mathrm{P}$, $\mathrm{Mg})$.

\subsection{Statistical Analysis}

The significance of the differences between classes (LCC and HCC) was tested by analysis of variance, using the general linear model procedure of SPSS (IBM SPSS Statics 24, Armonk, NY, USA), according to the following univariate model:

$$
\mathrm{Y}_{\mathrm{ijk}}=\mu+\mathrm{C}_{\mathrm{i}}+\mathrm{T}_{\mathrm{j}}+\varepsilon_{\mathrm{ijk}}
$$

where: $\mathrm{Y}_{\mathrm{ijk}}=$ dependent variable; $\mu$ = overall mean; $\mathrm{C}_{\mathrm{i}}=$ effect of milk somatic cell class (LCC or HCC) $(i=1,2) ; T_{j}=$ effect of trial $(j=1, \ldots .10) ; \varepsilon_{i j k}=$ residual error. The significance of the differences was tested by least significant differences method.

Data were also processed by the Pearson product moment correlation coefficient, to measure the degree of the linear relationship between the somatic cell content of the whole evening milk (expressed as somatic cell score) and cheese yield, and between the vat milk chemical characteristics and cheese yield.

\section{Results and Discussion}

\subsection{Chemical Composition and Physico-Chemical Properties of Vat Milk}

The average somatic cell count in LCC WE-milk was 233,000 cells/mL (minimum 122,000; maximum 341,000 cells $/ \mathrm{mL}$ ) and 538,000 cells/mL (minimum 407,000; maximum 886,000 cells $/ \mathrm{mL}$ ) in HCC WE-milk. The fat and protein contents were 3.70 and $3.61 \mathrm{~g} / 100 \mathrm{~g}$, and 3.18 and $3.06 \mathrm{~g} / 100 \mathrm{~g}$, respectively for LCC and HCC-milk.

Chemical composition, physicochemical properties, and somatic cells count of LCC and HCC vat milk are described in Table 1. Casein, casein number, phosphorus, chloride, titratable acidity, and $\mathrm{pH}$ showed different values, with $p \leq 0.05$.

The HCC V-milk, in comparison with the LCC V-milk, was characterized by lower casein $(2.43$ vs. $2.57 \mathrm{~g} / 100 \mathrm{~g} ; p \leq 0.05)$ and phosphorus ( $88.37 \mathrm{vs.} 92.46 \mathrm{mg} / 100 \mathrm{~g} ; p \leq 0.05)$ contents, lower casein number value (77.03 vs. $77.80 \% ; p \leq 0.05$ ) and higher chloride content (111.88 vs. $104.12 \mathrm{mg} / 100 \mathrm{~g} ; p$ $\leq 0.05)$. Moreover, titratable acidity was lower ( 3.16 vs. $\left.3.34^{\circ} \mathrm{SH} / 50 \mathrm{~mL} ; p \leq 0.05\right)$ and the $\mathrm{pH}$ value was higher (6.77 vs. 6.71 units; $p \leq 0.05$ ). Overall, the composition profile was less favorable for cheesemaking. In fact, cheese yield strictly depends on fat and casein contents [23], and $\mathrm{pH}$, acidity, and mineral contents of the milk are closely linked to the rennet-coagulation properties [24].

The results are in accordance with those reported in the literature and collected in a review by Le Maréchal et al. [1]. More specifically, Franceschi et al. [11], in research performed on 248 Parmigiano Reggiano vat milk samples (202 with less than 400,000 cells/mL and 48 with more than 400,000 cells/mL), 
reported lower casein content ( 2.43 vs. $2.47 \mathrm{~g} / 100 \mathrm{~g} p \leq 0.05)$, casein number (76.78 vs. $77.42 p \leq 0.05)$, and titratable acidity ( $3.24 \mathrm{vs} .3 .29^{\circ} \mathrm{SH} / 50 \mathrm{~mL} p \leq 0.05$ ) for milk with more than $400,000 \mathrm{cells} / \mathrm{mL}$ than milk with less than 400,000. Summer et al. [25] observed, in a study conducted on 26 single quarter milk samples (13 with less and 13 with more than 400,000 cells $/ \mathrm{mL}$ ), a lower phosphorous content ( 87.76 vs. $89.71 \mathrm{mg} / 100 \mathrm{~g} p \leq 0.05)$ and a higher chloride content $(135.17 \mathrm{vs.} 99.43 \mathrm{mg} / 100 \mathrm{~g} p \leq 0.01$ ).

All these changes in HCC milk are due to an increase of the concentration of whey protein $[26,27]$ and sodium chloride [25], which come directly from blood [27], and a decrease of phosphorus [12,25] and casein [10], caused by decreased mammary activity and an increase of proteolytic enzymatic activity $[26,28]$. Being that titratable acidity and $\mathrm{pH}$ were highly correlated with the contents of casein and phosphorus, the significant lower and higher values of these two parameters, respectively, in HCC V-milk are explained.

Table 1. Chemical composition and physicochemical properties parameters of vat milk with less than 400,000 (Low Cell Count (LCC)) and more than 400,000 cells/mL (High Cell Count (HCC)) (least square mean values \pm standard error).

\begin{tabular}{|c|c|c|c|c|c|}
\hline Parameter & Unit of Measure & $\begin{array}{c}\mathrm{LCC}^{1} \\
n^{2}=10\end{array}$ & $\begin{array}{c}\mathrm{HCC}^{1} \\
n^{2}=10\end{array}$ & $\mathrm{SE}^{3}$ & $p^{4}$ \\
\hline Crude protein & $\mathrm{g} / 100 \mathrm{~g}$ & 3.30 & 3.16 & 0.06 & NS \\
\hline Casein & $\mathrm{g} / 100 \mathrm{~g}$ & 2.57 & 2.43 & 0.05 & $*$ \\
\hline Casein number & $\%$ & 77.80 & 77.03 & 0.31 & * \\
\hline $\mathrm{NPN} \times 6.38$ & $\mathrm{~g} / 100 \mathrm{~g}$ & 0.17 & 0.16 & 0.01 & NS \\
\hline True protein & $\mathrm{g} / 100 \mathrm{~g}$ & 3.13 & 3.00 & 0.06 & NS \\
\hline Fat & $\mathrm{g} / 100 \mathrm{~g}$ & 2.75 & 2.68 & 0.05 & NS \\
\hline Fat to casein ratio & Value & 1.07 & 1.10 & 0.01 & NS \\
\hline Calcium & $\mathrm{mg} / 100 \mathrm{~g}$ & 114.75 & 114.17 & 1.54 & NS \\
\hline Phosphorus & $\mathrm{mg} / 100 \mathrm{~g}$ & 92.46 & 88.37 & 1.32 & $*$ \\
\hline Magnesium & $\mathrm{mg} / 100 \mathrm{~g}$ & 11.12 & 10.70 & 0.25 & NS \\
\hline Chloride & $\mathrm{mg} / 100 \mathrm{~g}$ & 104.12 & 111.88 & 2.72 & * \\
\hline Titratable acidity & ${ }^{\circ} \mathrm{SH} / 50 \mathrm{~mL}$ & 3.34 & 3.16 & 0.04 & * \\
\hline $\mathrm{pH}$ & Value & 6.71 & 6.77 & 0.02 & * \\
\hline Somatic cell count & $10^{3}$ cells $/ \mathrm{mL}$ & 146 & 259 & 5 & $* *$ \\
\hline
\end{tabular}

\subsection{Cheese Yield and Cheesemaking Losses of Vat Milk}

The least square mean values of cheese yield are shown in Table 2. Both actual cheese yields at 24 months of ripening and dry yield at 24 months of ripening were significantly lower in HCC cheesemaking than LCC (Figure 1).

In the literature, there is a general consensus about the negative relationships between somatic cells of milk and its cheese yield capacity. In hard Cheddar cheese production, a decrease of the yield was reported for milk with more than 100,000 cells/mL [4] and more than 300,000 cells/mL [29]. Similarly, in cottage (a soft cheese) production, Klei et al. [5] found that cheese yield efficiency was $4.34 \%$ lower for high somatic cell milk (mean value 872,000 cells $/ \mathrm{mL}$ ) than for low somatic cell milk $(83,000$ cells $/ \mathrm{mL}$ ). In contrast, Mazal et al. [30] observed no significant differences in Prato cheese yield when comparing milk with less than 200,000 cells $/ \mathrm{mL}$ and more than 600,000 cells $/ \mathrm{mL}$ (10.4 vs. $9.2 \mathrm{~kg} / 100 \mathrm{~kg}$, respectively). Such different results could depend on the low number of comparison made (only three comparative trials) and differences in cheesemaking technologies between Prato cheese (a soft cheese made with pasteurized milk) and hard cheeses. For Parmigiano Reggiano, the decrease of yield measured $24 \mathrm{~h}$ after the extraction of the curd started at 300,000 cells $/ \mathrm{mL}$ [12]. The difference of the mean value of the 24-month cheese yield between the LCC milk and HCC was $0.65 \mathrm{~kg} / 100 \mathrm{~kg}$ of processed milk, corresponding to a difference of $9.64 \%$. 
Table 2. Cheese yield and cheesemaking losses of vat milk with less than 400,000 (LCC) and more than 400,000 cells/mL (HCC) (least square mean values \pm standard error).

\begin{tabular}{|c|c|c|c|c|c|}
\hline Parameter & $\begin{array}{l}\text { Unit of } \\
\text { Measure }\end{array}$ & $\begin{array}{c}\text { LCC }^{1} \\
n^{2}=10\end{array}$ & $\begin{array}{c}\text { HCC }^{1} \\
n^{2}=10\end{array}$ & $\mathrm{SE}^{3}$ & $p^{4}$ \\
\hline \multicolumn{6}{|l|}{ Cheese yield: } \\
\hline Actual cheese yield at 24 months & $\mathrm{kg} / 100 \mathrm{~kg}$ & 7.39 & 6.74 & 0.18 & * \\
\hline Dry yield at 24 months & $\mathrm{kg} / 100 \mathrm{~kg}$ & 5.19 & 4.74 & 0.20 & $*$ \\
\hline \multicolumn{6}{|l|}{ Cheese characteristics: } \\
\hline Moisture & $\mathrm{g} / 100 \mathrm{~g}$ & 29.84 & 29.78 & 0.28 & NS \\
\hline \multicolumn{6}{|l|}{ Estimated cheesemaking losses: } \\
\hline Protein & $\%$ & 26.59 & 26.92 & 0.28 & NS \\
\hline Casein & $\%$ & 5.65 & 5.13 & 0.22 & NS \\
\hline Fat & $\%$ & 16.13 & 20.16 & 0.87 & $* *$ \\
\hline Phosphorus & $\%$ & 49.86 & 50.28 & 0.87 & NS \\
\hline Calcium & $\%$ & 33.86 & 34.71 & 0.51 & NS \\
\hline Magnesium & $\%$ & 76.92 & 77.36 & 1.69 & NS \\
\hline
\end{tabular}

${ }^{1}$ Classification was based on SCC of the whole evening milk; ${ }^{2}$ Number of samples; ${ }^{3}$ Standard error; ${ }^{4} p$-value: NS, $p>0.05 ;{ }^{*} p \leq 0.05 ;{ }^{* *} p \leq 0.01$.

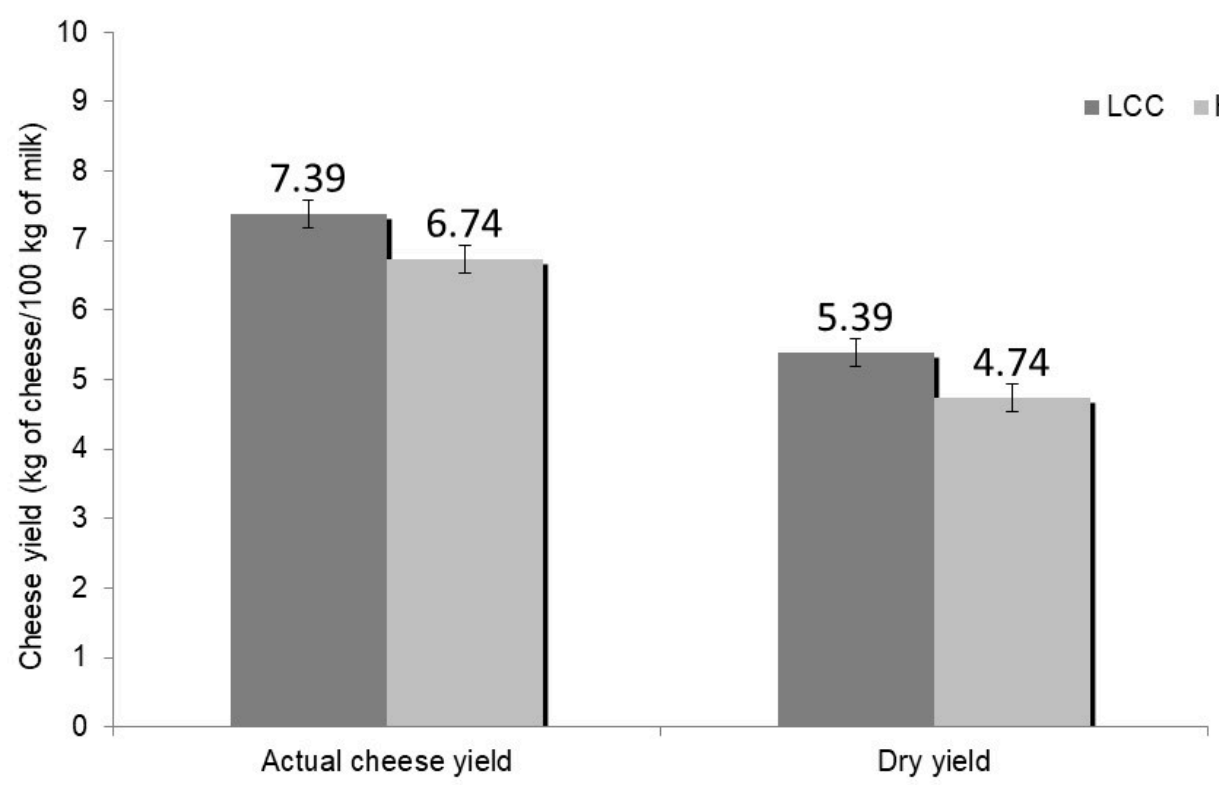

Figure 1. Cheese yield at 24 months ripening from milk with less than 400,000 (Low Cell Count (LCC)) and more than 400,000 cells/mL (High Cell Count (HCC)) (least square mean values). Classification was based on SCC of the whole evening milk. For both, LCC and HCC means differ with a $p$-value $\leq 0.05$.

The difference in cheese yield were not caused by differences in water retention (the moisture of the cheeses was the same); this was confirmed by the calculation of the adjusted dry yield. In effect, cheese yield is directly proportional to casein and fat content [23]; moreover, the worsening of rennet coagulation properties [31], linked to the decrease in phosphorus and calcium, and to the reduction of the casein content itself, leads to an increase in the loss of fat in the whey.

In Table 2, fat, protein, and main minerals estimated cheesemaking losses are also shown. Only for fat losses, different average values $(p \leq 0.01)$ were observed between LCC and HCC V-milks, with higher losses in HCC-cheesemaking than in LCC (Figure 2). In a recent paper, Franceschi et al. [31] reported that the average fat loss in Parmigiano Reggiano, calculated on 288 cheesemaking trials, was $16.93 \%$. In the present study, the fat loss in LCC-cheesemaking was in agreement with this value, while fat loss of the HCC-cheesemaking is much higher than in Franceschi et al. [31]. Poor efficiency of HCC curd in retaining fat into the casein reticulum may be both related to undesired structural modification 
of the curd and/or loss of integrity of the fat globule, resulting from the increased activities of plasmin and lipases in milk collected from infected-glands [4,32]. This observation was confirmed by the positive and significant correlation found between milk casein content and fat losses and between milk fat to casein ratio and fat losses (Table 3).

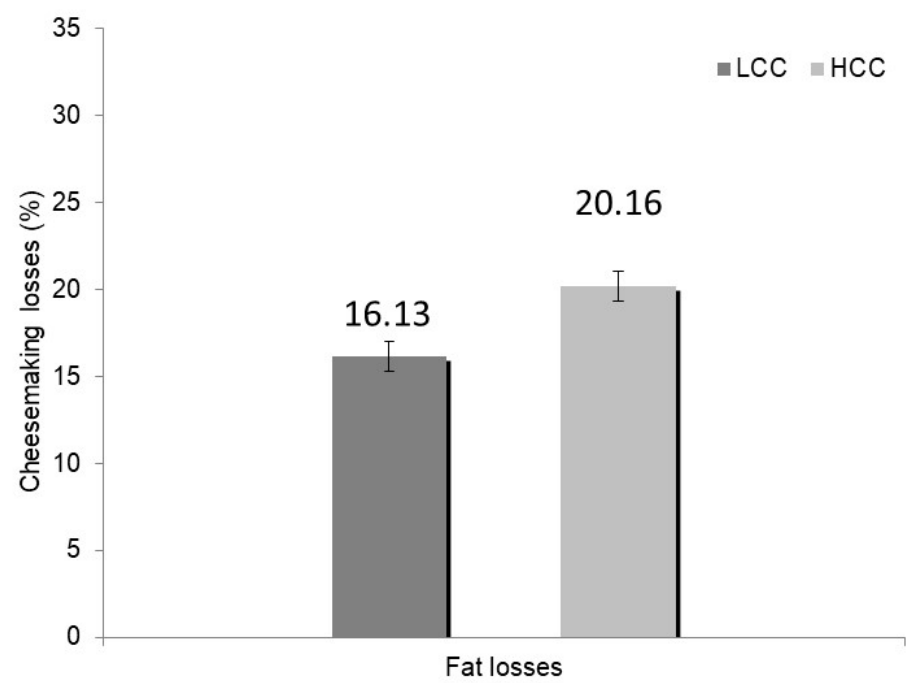

Figure 2. Cheesemaking fat losses of milk with less than 400,000 (LCC) and more than 400,000 cells/mL (HCC) (least square mean values). Classification was based on somatic cell count (SCC) of the whole evening milk. LCC and HCC means differ with a $p$-value $\leq 0.01$.

Table 3. Pearson correlation coefficient $(r)$ between somatic cell content of whole evening milk, cheese yield and cheesemaking losses, and between the vat milk chemical parameters, cheese yield and cheesemaking losses.

\begin{tabular}{|c|c|c|c|c|c|c|}
\hline & \multicolumn{2}{|c|}{ Cheese Yield $^{1}$} & \multicolumn{2}{|c|}{ Protein Losses } & \multicolumn{2}{|c|}{ Fat Losses } \\
\hline & $r$ & $p^{2}$ & $r$ & $p^{2}$ & $r$ & $p^{2}$ \\
\hline Somatic cells ${ }^{3}$ & -0.57 & * & 0.06 & NS & 0.34 & NS \\
\hline Crude protein & 0.68 & * & 0.03 & NS & -0.58 & $* *$ \\
\hline Casein & 0.69 & * & -0.20 & NS & -0.64 & $* *$ \\
\hline Fat & 0.60 & * & -0.09 & NS & -0.34 & NS \\
\hline Fat to casein ratio & -0.18 & NS & 0.15 & NS & 0.46 & $*$ \\
\hline
\end{tabular}

${ }^{1}$ At 24 months ripening; ${ }^{2} p$-value: NS, $p>0.05 ;{ }^{*} p \leq 0.05 ;{ }^{* *} p \leq 0.01 ;{ }^{3}$ Expressed as somatic cell score (SCS).

Pearson product moment correlation coefficients between WE-milk somatic cell content, cheese yield and cheesemaking losses, and between V-milk characteristics, cheese yield, and cheesemaking losses, are shown in Table 3.

A negative and significant correlation was observed between SCC (measured on the corresponding WE-milk before natural creaming) and V-milk cheese yield at 24 months ripening. Conversely, V-milk cheese yields were positively correlated with contents of protein, casein, and fat. Formaggioni et al. [23] reported, for their prediction formulas of the estimated cheese yield for hard cooked cheese types, a similar correlation between Parmigiano Reggiano cheese yield, and the content of milk crude protein, casein, and fat constituents. Furthermore, the same positive correlations are reported in other cheese typologies, as Grana Padano [33] and Saint-Nectaire cheeses [34].

\section{Conclusions}

In conclusion, the present study allowed quantifying the negative impact of milk somatic cell content on the cheese yield in manufacturing Parmigiano Reggiano cheese. The decrease of the yield both derives from the less favorable chemical composition of milk and from reduced efficiency of the coagulum to retain the fat fraction. It is very important to know that, even though Regulation (EC) 
no $853 / 2004$ [2] indirectly allows to submit to cheesemaking milk with more than 400,000 cells $/ \mathrm{mL}$, due to the limited number of mandatory analyses, this must be avoided. The economic impact of the connected reduction of the cheese yield is not negligible, and could compromise profitability.

Author Contributions: Conceptualization, A.S., P.F. (Piero Franceschi), and M.F.; methodology, A.S., P.F. (Piero Franceschi) and M.M.; software, P.F. (Piero Franceschi) and P.F. (Paolo Formaggioni); validation, A.S., M.M., P.F. (Paolo Formaggioni) and P.F. (Piero Franceschi); formal analysis, P.F. (Piero Franceschi), P.F. (Paolo Formaggioni); investigation, M.M., and A.S.; resources, A.S. and M.M.; data curation, P.F. (Piero Franceschi), P.F. (Paolo Formaggioni) and M.F.; writing-original draft preparation, P.F. (Piero Franceschi), M.F. and P.F. (Paolo Formaggioni).; writing - review and editing, M.F., M.M., and P.F. (Paolo Formaggioni); visualization, P.F. (Piero Franceschi), A.S., M.M., and M.F.; supervision, A.S. and M.F.; project administration, A.S. and M.M. All authors have read and agreed to the published version of the manuscript.

Funding: This research received no external funding.

Conflicts of Interest: The authors declare that there are no conflicts of interest in this research article.

\section{References}

1. Le Maréchal, C.; Thiéry, R.; Vautor, E.; Le Loir, Y. Mastitis impact on technological properties of milk and quality of milk products-A review. Dairy Sci. Technol. 2011, 91, 247-282. [CrossRef]

2. Regulation (EC) No 853/2004 of the European Parliament and of the Council of 29 April 2004, Laying Down Specific Hygiene Rules for on the Hygiene of Foodstuffs, Web Site. Available online: https://eur-lex.europa. eu/LexUriServ/LexUriServ.do?uri=OJ:L:2004:139:0055:0205:en:PDF (accessed on 12 December 2019).

3. Ali, A.E.; Andrews, A.T.; Cheeseman, G.C. Influence of elevated somatic cell count on casein distribution and cheese-making. J. Dairy Res. 1980, 47, 393-400. [CrossRef]

4. Barbano, D.M.; Rasmussen, R.R.; Lynch, J.M. Influence of milk somatic cell count and milk age on cheese yield. J. Dairy Sci. 1991, 74, 369-388. [CrossRef]

5. Klei, L.; Yun, J.; Sapru, A.; Lynch, J.; Barbano, D.M.; Sears, P.; Galton, D. Effects of milk somatic cell count on Cottage cheese yield and quality. J. Dairy Sci. 1998, 81, 1205-1213. [CrossRef]

6. Summer, A.; Franceschi, P.; Formaggioni, P.; Malacarne, M. Characteristics of raw milk produced by free-stall or tie-stall cattle herds in the Parmigiano-Reggiano cheese production area. Dairy Sci. Technol. 2014, 94, 581-590. [CrossRef]

7. Lombardy and Emilia Romagna Experimental Zootechnical Institute (IZSLER) Web Site. Available online: https://www.izsler.it/pls/izs_bs/v3_s2ew_consultazione.mostra_pagina?id_pagina=524 (accessed on 12 December 2019).

8. Summer, A.; Lora, I.; Formaggioni, P.; Gottardo, F. Impact of heat stress on milk and meat production. Anim. Front. 2019, 9, 39-46. [CrossRef]

9. Council Regulation (EC) No 510/2006 of 20 March 2006 on the Protection of Geographical Indications and Designations of Origin for agricultural Products and Foodstuffs, Web Site. Available online: https:/eur-lex. europa.eu/legal-content/EN/TXT/PDF/?uri=CELEX:32006R0510\&from=en (accessed on 12 December 2019).

10. Summer, A.; Formaggioni, P.; Franceschi, P.; Di Frangia, F.; Righi, F.; Malacarne, M. Cheese as functional food: The example of Parmigiano Reggiano and Grana Padano. Food Tech. Biotech. 2017, 55, 277-289. [CrossRef]

11. Franceschi, P.; Summer, A.; Sandri, S.; Formaggioni, P.; Malacarne, M.; Mariani, P. Effects of the full cream milk somatic cell content on the characteristics of vat milk in the manufacture of Parmigiano-Reggiano cheese. Vet. Res. Commun. 2009, 33 (Suppl. 1), 281-283. [CrossRef]

12. Summer, A.; Franceschi, P.; Formaggioni, P.; Malacarne, M. Influence of milk somatic cell content on Parmigiano-Reggiano cheese yield. J. Dairy Res. 2015, 82, 222-227. [CrossRef]

13. IDF Standard. Milk, Enumeration of Somatic Cells, Part 2: Guidance on the Operation of Fluoro-Opto-Electronic Counters; 148-2/ISO13366-2; International Dairy Federation Standard: Brussels, Belgium, 2006.

14. IDF Standard. Milk and Liquid Milk Products, Guidelines for the Application of Mid-Infrared Spectrometry; 141/ISO9622; International Dairy Federation Standard: Brussels, Belgium, 2013.

15. IDF Standard. Milk, Determination of Fat Content, Acido-Butyrometric (Gerber Method); 238-2/ISO19662-2; International Dairy Federation Standard: Brussels, Belgium, 2018. 
16. Association of Official Analytical Chemists [AOAC]. Nitrogen (total) in milk, method no. 991.20. In Official Methods of Analysis of AOAC International, 18th ed.; Horowitz, W., Ed.; AOAC International: Gaithersburg, MD, USA, 2005; pp. 10-12.

17. Association of Official Analytical Chemists [AOAC]. Noncasein nitrogen content of milk, method no. 998.05. In Official Methods of Analysis of AOAC International, 18th ed.; Horowitz, W., Ed.; AOAC International: Gaithersburg, MD, USA, 2005; pp. 50-51.

18. Association of Official Analytical Chemists [AOAC]. Nonprotein nitrogen in whole milk, method no. 991.21. In Official Methods of Analysis of AOAC International, 18th ed.; Horowitz, W., Ed.; AOAC International: Gaithersburg, MD, USA, 2005; pp. 12-13.

19. Malacarne, M.; Criscione, A.; Franceschi, P.; Tumino, S.; Bordonaro, S.; Di Frangia, F.; Marletta, D.; Summer, A. Distribution of $\mathrm{Ca}, \mathrm{P}$ and $\mathrm{Mg}$ and casein micelle mineralisation in donkey milk from the second to ninth month of lactation. Int. Dairy J. 2017, 66, 1-5. [CrossRef]

20. Malacarne, M.; Criscione, A.; Franceschi, P.; Bordonaro, S.; Formaggioni, P.; Marletta, D.; Summer, A. New insights into chemical and mineral composition of donkey milk throughout nine months of lactation. Animals 2019, 9, 1161. [CrossRef] [PubMed]

21. Shook, G.E.; Schutz, M.M. Selection on somatic cell score to improve resistance to mastitis in the United States. J. Dairy Sci. 1994, 77, 648-658. [CrossRef]

22. IDF Standard. Cheese and Processed Cheese, Determination of the Total Solids Content (Reference Method); 4/ISO5534; International Dairy Federation Standard: Brussels, Belgium, 2004.

23. Formaggioni, P.; Summer, A.; Malacarne, M.; Franceschi, P.; Mucchetti, G. Italian and Italian-style hard cooked cheeses: Predictive formulas for Parmigiano-Reggiano 24 h cheese yield. Int. Dairy J. 2015, 51, 52-58. [CrossRef]

24. Malacarne, M.; Franceschi, P.; Formaggioni, P.; Sandri, S.; Mariani, P.; Summer, A. Influence of micellar calcium and phosphorus on rennet coagulation properties of cows milk. J. Dairy Res. 2014, 81, 129-136. [CrossRef] [PubMed]

25. Summer, A.; Franceschi, P.; Malacarne, M.; Formaggioni, P.; Tosi, F.; Tedeschi, G.; Mariani, P. Influence of somatic cell count on mineral content and salt equilibria of milk. Ital. J. Anim. Sci. 2009, 8 (Suppl. 2), 435-437. [CrossRef]

26. Urech, E.; Puhan, Z.; Schällibaum, M. Changes in milk protein fraction as affected by subclinical mastitis. J. Dairy Sci. 1999, 82, 2402-2411. [CrossRef]

27. Somers, J.; O’Brien, B.; Meany, W.; Kelly, A.L. Heterogeneity of proteolytic enzyme activities in milk samples of different somatic cell count. J. Dairy Res. 2003, 70, 45-50. [CrossRef]

28. Shennan, D.B.; Peaker, M. Transport of milk constituents by the mammary gland. Physiol. Rev. 2000, 80, 925-951. [CrossRef]

29. Politis, I.; Ng-Kwai-Hang, K.F. Association between somatic cell count of milk and cheese-yielding capacity. J. Dairy Sci. 1988, 71, 1720-1727. [CrossRef]

30. Mazal, G.; Vianna, P.C.B.; Santos, M.V.; Gigante, M.L. Effect of somatic cell count on Prato cheese composition. J. Dairy Sci. 2007, 90, 630-636. [CrossRef]

31. Franceschi, P.; Malacarne, M.; Formaggioni, P.; Stocco, G.; Cipolat-Gotet, C.; Summer, A. Effect of season and cheese-factory on cheese-making efficiency in Parmigiano Reggiano cheese manufacture. Foods 2019, 8, 315. [CrossRef] [PubMed]

32. Fleminger, G.; Ragones, H.; Merin, U.; Silanikove, N.; Leitner, G. Chemical and structural characterization of bacterially-derived casein peptides that impair milk clotting. Int. Dairy J. 2011, 21, 914-920. [CrossRef]

33. Pretto, D.; De Marchi, M.; Penasa, M.; Cassandro, M. Effect of milk composition and coagulation traits on Grana Padano cheese yield under field conditions. J. Dairy Res. 2013, 80, 1-5. [CrossRef] [PubMed]

34. Verdier-Metz, I.; Coulon, J.B.; Pradel, P. Relationship between milk fat and protein contents and cheese yield. Anim. Res. 2001, 50, 365-371. [CrossRef]

(C) 2020 by the authors. Licensee MDPI, Basel, Switzerland. This article is an open access article distributed under the terms and conditions of the Creative Commons Attribution (CC BY) license (http://creativecommons.org/licenses/by/4.0/). 